\title{
Caveat Emptor: A new form of participatory mapping and its ethical implications for Participatory GIS
}

\author{
Koshiro Suzuki ${ }^{\text {a, }}$ * \\ ${ }^{a}$ Faculty of Humanities, University of Toyama 1,lichthoffen@hotmail.com \\ * Corresponding author
}

\begin{abstract}
Since the 1990s, the consolidation of technological platforms for geographic information has expanded the possibilities of geospatial analysis in conjunction with GIS. Even ordinary people have become capable of interactive web communication with electronic maps thanks to the emergence of smartphones compatible with GeoAPI (application programming interface) and Wi-Fi access. Many studies have described the progress that built a solid foundation of web democracy by embodying people-powered mapping circumstances in the so-called Web 2.0. However, we have yet to acquire geographic information ethics that sufficiently respond to new threats stemming from these circumstances. In the present paper, the author instantiated a user-generated online mapping website named Caveat Emptor (a.k.a. Oshimaland) to investigate the necessity of a geographic information ethics 2.0. By incorporating Suler's (2004) concept of online disinhibition effects, the author clarified that people can utilise new technologies both in good ways and bad, from behind the safety of a mask. Despite the omnoptic mutual surveillance environment, the associated participants in actual scenes of cyberspace are not always restrained. This explains why it is necessary to update geographic information ethics to be compatible with Web 2.0 circumstances. Four types of ethical challenges were identified that are concerned with (1) the extent to which volunteered geographic information (VGI) should be recruited in constructing collective knowledge, (2) how to build a renewed geographic information ethics in general, (3) how to construct a gradation in geographic information ethics in practice, and (4) what scientific knowledge should be referred to in the contiguous areas of specialisation.
\end{abstract}

Keywords: Caveat Emptor, geographic information ethics 2.0, PGIS

\section{Introduction}

\subsection{Ubiquitous mapping advantages}

Since the 1990s, the technological platforms of geographic information, such as the consolidation of geostatistical data, high precision GPS, improvement of PC processing capability, and expedited LAN access, have expanded the possibilities of geospatial analysis in conjunction with GIS. Geographers gradually became aware of the magnitude of the social impacts of the GISystem, which became capable of analysing and outputting even data at a personal level (Miller, 2007). From the first decade of the 2000s onward, there was further progress in geographic information technologies (GIT). Even ordinary people became capable of interactive web communication with electronic maps thanks to the emergence of smartphones compatible with GeoAPI (application programming interface) and Wi-Fi access. As many studies have indicated, this progress built a solid foundation of web democracy by embodying the people-powered mapping circumstances of the socalled Web 2.0 (Haklay et al., 2008).

In the field of GIScience, one of the fruitful benefits emerging from the advance was the use of GIS as a tool for social participation and public involvement, or what we call participatory GIS (PGIS) (McCall and Dunn, 2012) and public participation GIS, (PPGIS) (Sieber, 2006). The evolution of GIT enabled the public to become senders, sharers, and communicators of geographic information using social networking services (SNS) and online mapping devices (Crampton, 2010). Sometimes, these grassroots mappers voluntarily participate in regional policy planning and local governance, which is referred to as bottom-up GIS (Talen, 2000), or volunteer geographic information (VGI) (Goodchild, 2007) and neogeography (Turner, 2006). The movement was largely enabled by geospatial information technology-aided ubiquitous mapping and cartography (Morita, 2005; Reichenbacher, 2007; Gartner et al., 2007).

Given the aim of fair-use and the communisation of geographic information, some open-source GIS programs and web-based open-source mapping platforms were established (Willis, 2011; Neteler et al., 2012). This progress enabled grassroots mappers to use GIT in postdisaster construction and damage repair processes by digitising satellite imagery of the afflicted areas on OpenStreetMap (OSM) to find ways around damaged roads (Norheim-Hagtun and Meier, 2010). These crisismapping actions have demonstrated their efficacy in the aftermath of the 2011 earthquake off the Pacific coast of 
Tōhoku (Seto, 2011). Generally, cartographers positively interpret these actions as people-powered, net-rooted, undisciplined, alternative, and a Dionysian means of mapping (Kingsbury and Jones, 2009). Sometimes, such empowered mappers challenge the hidden 'places and facilities, including a panoply of military installations, sites relating to state security, policing and prisons, and increasingly "strategic" national assets and infrastructures' (Perkins and Dodge, 2009: 546) revealed and shared through GIT.

\subsection{Privacy invasion as a potential threat}

Whereas a prodigious amount of research has accumulated concerning the relation between GIS and society in relevant areas, it has mainly focused on the positive outcomes of the development as indicated above. Surprisingly little attention has been paid to potential threats except for discussions relating to invasion of privacy. Moreover, those privacy studies centred appreciable interest on the surveillance of geographic space as an exercise of public powers (Armstrong, 2002). Some scholars coined the term 'geosurveillance' (Crampton, 2003) to critically discuss the potential risks of privacy infringement that public authorities and SNS providers can collect to aggregate users' attributes and location information. Although the development of information and communication technology permits people to convey geographic information in a more friendly manner, users remain even more closely constrained because of geosurveillance (Monmonier, 2002). Dobson and Fisher (2003) termed the situation where 'a practice in which one entity, the master, coercively or surreptitiously monitors and exerts control over the physical location of another individual, the slave' (p. 48) as 'geoslavery'. Many scholars have metaphorically referred to the Big Brother motif from George Orwell's famous novel 1984 to describe the power and position of the master (e.g. Klinkenberg, 2007; Propen, 2005), and to the rendition of Bentham's panopticon as one pertaining to the systems and techniques of monitoring (Dobson and Fisher 2007; Koskela, 2002). Although many studies have been extremely conscious of the potential risks of geosurveillance by public powers, their discussions concerning privacy infringement at the individual level show much less diversity.

Meanwhile, in the Web 2.0 era, the panoptic one-tomany relationship has transformed itself to a manysurveilling-the-many situation in what Shilton (2009) described as 'little brothers' and Rose-Redwood (2006) termed the omnopticon. In such views, the progress of PGIS may encompass the constitution of the participatory panopticon and total loss of privacy (Whitaker, 1999). Kawaguchi and Kawaguchi (2012) reformulated the omnopticon as paradoxical others for describing the feeling of discomfort disclosed in Google street view. Liberally interpreted, they suggest that such developments as the omnoptic mutual surveillance environment restrains and intermediates between people and deviant behaviours by a sort of unseen hand of God.

Before the Web 2.0 era, most people who could create and manage maps were knowledgeable experts who generally had been educated in professional ethics, and had internalised their codes. However, in circumstances where ubiquitous mapping prevails, people can participate in mapping behaviour far more casually without being aware that they are engaged in a position of power to create geographic information; nor do they require knowledge of cartography and ethics. Thus, the premise that the net-rooted, undisciplined, alternative, and Dionysian people do what the experts expect of them is no longer applicable.

\subsection{Geographic information ethics 2.0}

While PGIS/PPGIS struggled to achieve an online democracy and lower the technical/societal barriers for people's social participation, an enormous amount of research has revealed how people of colour, the non-elite, women, and non-English-speaking people who live in rural areas or in the global South are more likely to be underrepresented online (Carraro and Wissink, 2018). Therefore, PGIS/PPGIS was initially intended to primarily enhance understanding and awareness about the surroundings of the targeted people, and to improve 'the quality of planning through a participatory approach and facilitate inter-generational knowledge exchange and dialogue with disadvantaged communities and their leaders' (Verplanke et al., 2016: 310).

The targeted people were not only disadvantaged and indigenous, but did not have exit rights because of the effects of heavily deployed geographic information technology (Fox et al., 2006). This disadvantage provided an ethical justification to researchers and planners, who became involved in empowerment activities. In fact, numerous case studies focused on marginalised people, regions, and countries (Weiner et al, 1995; Fox, 2002; Williams and Dunn, 2003). Essentially, PGIS/PPGIS conveyed the nuances of community development and landscape ecology, and the aspiration to empower those who were disadvantaged and marginalised through GIS technology (Chapin et al., 2005).

GIT and PGIS/PPGIS are new to the people in such areas, at least in the early phase, suggesting that an anisotropic (interactive but not bidirectional) social relationship develops in the projects between those who empower and/or manage and those who are empowered and/or participate in terms of jurisdictional authority. Sometimes, these elite-driven mapping projects encompass social and environmental change in communities and cause unintended consequences, such as increased conflict among villagers, loss of indigenous conceptions of space, and increased privatisation of land (Fox et al., 2008). Therefore, ethics related to PGIS/PPGIS were developed to provide a code of professional ethics based on scholarly debates in the early and mid-1990s (Rambaldi et al., 2006). Consequently, although we became technically capable of interactive 


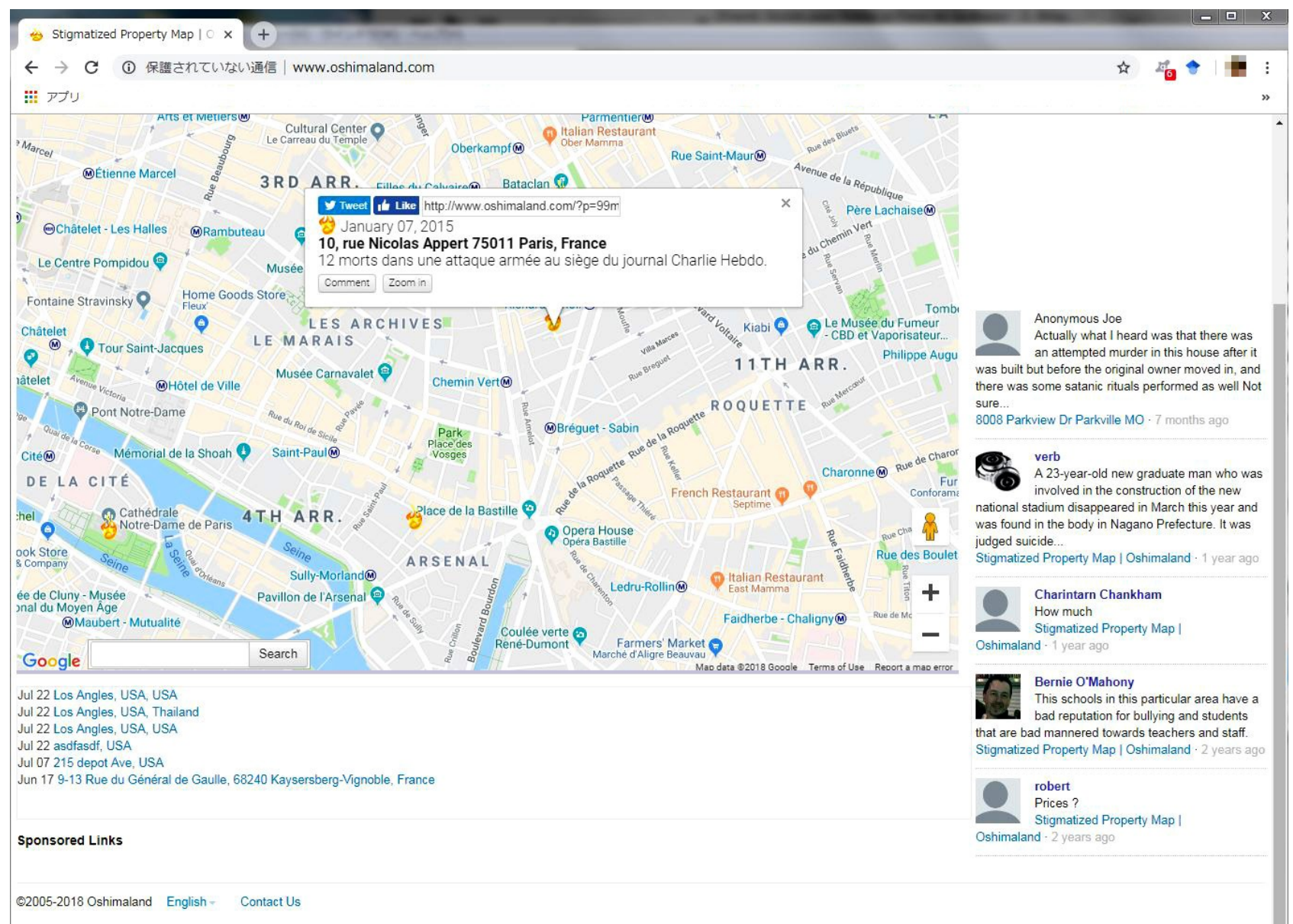

Figure 1. A screenshot of the top page of the website http://www.oshimaland.com (as of 13 Sept. 2018).

people-powered mapping owing to the recent rapid progress in the GIT and PGIS movement, our geographic information ethics remained in the 1.0 generation, and are now becoming insufficiently responsive to the new threats arising from Web 2.0 circumstances. It is necessary to redefine our idea of geographic information ethics from the first to the second generation to prepare for new ethical challenges in a ubiquitously mapped world. Therefore, in the present paper, the author instantiates a user-generated web mapping website named Caveat Emptor (a.k.a. Oshimaland) to investigate the necessity of geographic information ethics 2.0.

\section{Subject of the Research}

\subsection{Property with psychological defects}

In the Japanese legal system, the seller's warrant against concealed defects is defined in the Civil Code (Act No. 89 of 1896). In Article 570, Chapter 2, Part 3 of the code, it is prescribed that 'If there is any latent defect in the subject matter of a sale, the provisions of Article 566 shall apply mutatis mutandis; provided, however, that this shall not apply in cases of compulsory auction'. In Article $566(1)$, it is also mentioned that 'In cases where the subject matter of the sale is encumbered with the purpose of a superficies, an emphyteusis, an easement, a right of retention, or a pledge, if the buyer does not know the same and cannot achieve the purpose of the contract on account thereof, the buyer may cancel the contract. In such cases, if the contract cannot be cancelled, the buyer may only demand compensation for damages' (Ministry of Justice, 2018).

Defects of property can be categorised as physical, legally restrained, or psychological. According to several lower court judgements, psychological defects can be categorised into five types: property (1) where the toilet location faces toward the demon's gate (the northeastern direction, believed to be unlucky), (2) which has a history of suicide or murder, (3) adjacent to an office of gangsters, (4) with an annoying neighbour, or (5) adjacent to a sex business (Nagashima, 2018). Of the five types of defects, psychological defects due to suicides and murders are deeply linked to the scope of the current study. Although the psychological defects are subjective, and it is difficult to distinguish whether and to what degree the defects prejudice the economic value of the property, recent lower court precedents have sustained the premise that the lessor's failure to inform the lessee about the fact of suicide upon commitment to the lease is illegal (Kaneko, 2015; Nakato, 2015). Owing to the tacit social consensus stated above, it is a common practice in 
Japan that a real estate agency has the duty to disclose the facts of suicide or murder to, at least, the next occupier. In the meantime, it is important to note that the disclosure obligation is a type of established business practice. There is no uniform legal criterion over the terms and conditions of performance and this is left to the lessor's own judgement. Ultimately, this means that the lessee cannot access the whole record concerning the psychological defects of the property unless the lessors and/or real estate agencies are willing to comply with the disclosure.

\subsection{A digital archive of hideous properties}

In September 2005, Manabu Oshima (hereafter called MO), who identified himself as the managing director of a business corporation, Oshima-Teru, launched a website - Oshimaland (http://www.oshimaland.com/). He attached the motto caveat emptor, a Latin aphorism meaning 'Let the buyer beware' on the top page of the website. That was also the year when Google Maps were initially launched in February. As the immediacy of this temporal axis clearly demonstrates, Oshimaland embedded Google Maps on the top of the page, although in later years the base map was changed to OpenStreetMaps and Yahoo! Maps possibly because of the copyright claim (Figure 1).

Using GeoAPI, MO began to upload his uniquely collected information on properties with a history and records of suicide and murder, what were called 'stigmatised properties' on the site. A brief description of each incident, date and time of occurrence, outside shot, as well as the property location and address were pinned on the electronic map and displayed as clickable icons (Furuta 2010). For the first six years, he continued to prepare a digest of newspaper articles to construct a verified property map of psychological defects. Because the uploaded information was based on his personal efforts, the initial geographic distribution of the properties was spatially constrained and almost always confined to the realm of Tokyo's 23 wards. Although the web map caused a massive controversy over claims concerning the right to know and interference in business, MO acquired the information from authentic data, which is publicly available. In fact, he even successfully won a slander lawsuit in 2011 when sued by the landowner of a condominium.

One of the key components of the website was a 'public hearing'. According to MO, he erected it to gather the power of collective wisdom for properties with psychological defects even if the classification of many of them was uncertain (Furuta, 2010). He confirmed the details by checking newspapers and added the verified information to the web maps. The public hearing window contributed to a rapid growth in the number of cases with warranted information quality in a relatively short period of time.

\subsection{La rumeur d'Orléans in the digital age}

In 2011, there were several fundamental changes in the operational policy of the website. The most notable additions were the launch of an English version and the function of posting. In an interview report from a web journal in 2014, OM stated that he strove to maximise the access of many unspecified users because he was expecting them to correct mistakes and deficiencies. Meanwhile, he also confessed that the main duty involved in Oshimaland was website management rather than defect disclosure, and his status was closer to editor-inchief than investigator (Oshima, 2014). A flood of unmoderated posts from anonymous users exceeded the website's managerial capacity, and the authenticity of every post could not be ascertained. In contrast, the amount of posted information dramatically increased. Today, as of September 21, 2018, 54,851 posts have appeared from throughout Japan. The geographical scope has also expanded to every region of Japan, including remote islands, and a growing number of sites have appeared in foreign countries. This strongly suggests that the initial website came to mean the birth of a computerised focal point for rumours; it become functional as an artificial incubator of urban legends in cyberspace.

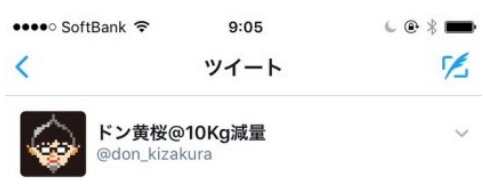

鳴呼、小学生からの親友が自殺した のだが、大島てるの事故物件に記載 されていて、大島てるを殺したい。 ここの運営の代表って誰ですか? 殺 していいんですか?もし、イイよっ て言ってくれる人がいたならば今か らその人を殺しに行きます。武器は そこら辺のスーパーに売ってる安も んの包丁買います。 2017/04/12 23:41 场所: 兵庫尼崎市 12 リッイート 5 いいね

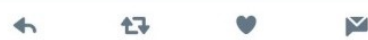

Figure 2. The death threat tweet (Retrieved from; https://togetter.com/li/1100265)

On April 21, 2017, an anonymous individual by the name of@don_kizakura made a death threat via twitter against the representative of Oshimaland, although his identity was determined and he was arrested within half a year. His tweet, 'Alas! My best friend since elementary school committed suicide in the wake of being listed on Oshimaland. I want to kill Oshima tomorrow. Who is the representative managing there? Can I kill him? If someone told me to go ahead, I would go to kill that person now. I will buy a cheap knife, as the weapon should be sold in a supermarket around the neighbourhood', raised penetrating questions of what is 
ethically right, regardless of whether the statement was true or not (Figure 2).

Managing a digital archive with such hideous properties includes potential risks that may encompass reputational damages for spreading rumours. If the administrator(s) claim that they preserve the public's right to information, it means that such a portal site possesses character of a public figure. It is impermissible to excuse individual conduct by its limitations and/or claim that the website belongs to the private sector. Because the recent progress in GIT lowered entry barriers, it has become far easier for anyone to exert influence online. However, those involved should recognise a commensurate sense of ethics and norms. Otherwise, the participatory mapping trend will be subject to anomie.

\section{Discussion and Conclusion}

In considering the reason why people post such unwarranted and negative information online, Suler's (2004) 'online disinhibition effect' offers numerous suggestions. While online, people 'do not have to worry about how others look or sound in response to what they say' and 'in the case of expressed hostilities or other deviant behaviors, the person can avert responsibility for those behaviors, almost as if superego restrictions and moral cognitive processes have been temporarily suspended from the online psyche' (Ibid., 322). He classified disinhibition in terms of its benign (positive) and toxic (negative) effects. In layman's terms, people can utilise new technologies both in good ways and in bad, from behind the safety of a mask.

Although Oshimaland once secured a certain degree of authenticity because of MO's manual investigation at the initial stage, the website had already become a medium for apocryphal rumours. Currently, Oshimaland can be thought as an electronic map operator of urban legends 'because they represent enduring social narratives, which reach wide audiences and potentially influence significant numbers of people' (Dagnall et al., 2017: 2). By linking a geographically identifiable spot to its own repugnant rumours, it semiotically articulates and stigmatises the place with the benefit gained from ubiquitous, peoplepowered mapping. As the present case clearly illustrates, the omnoptic mutual surveillance environment does not always restrain associate participants in the actual scenes of cyberspace. This explains why geographic information ethics must necessarily be updated for compatibility with Web 2.0 circumstances. To facilitate the discussion, we can sum up the presumed ethical challenges in four arguments.

First, ethical challenges must be concerned with the reliability of information. The range of VGI should be enlisted to construct collective knowledge. Perhaps, the most useful practice of VGI is OSM. In fact, there are numerous studies addressing the rectitude of OSM. For example, Girres and Touya (2010) conducted a reliability investigation into OSM data. Results showed that OSM had the advantages of responsiveness and flexibility, whereas the problematic aspect of heterogeneity in OSM data highly limited its possible applications.

In regard to heterogeneity, many studies used content analyses on Wikipedia that revealed a further risk of vandalism in creating collaborative knowledge. With the help of their history flow visualisation, Viégas et al. (2004) found five patterns of vandalism in Wikipedia, including (1) mass deletion, i.e. deletion of all contents on a page, (2) offensive copy, i.e. insertion of vulgarities or slurs, (3) phony copy, i.e. insertion of text unrelated to the page topic, (4) false redirection, i.e. linking to an unrelated or offensive term, and (5) idiosyncratic copy, i.e. adding text that is related to the topic of the page but which is clearly one-sided, not of general interest, or inflammatory. They also suggested technical and ethical solutions for reducing internet vandalism, such as a mechanism of watchlists and talk pages to raise awareness of accountability, a group consensus that a 'neutral point of view' is desirable, and incorporating the Wikipedia 'three-revert rule'. Perhaps, the difference in probability of encountering vandalism between Wikipedia and OSM is related to the degree of VGI inclusion. Any VGI-powered geographic information should overcome this problem of an inevitable trade-off.

The second ethical challenge is related to how we build a renewed geographic information ethics in general. While the previous studies demonstrate that we are beginning to have a code of conduct and respective functions in a particular collective knowledge structure, there are highly community-specific ramifications of the total 'Wikification' paradigm (Sui, 2008). As the present study implies, however, popularised collective mapping devices are widespread and we have yet to construct a means of nurturing geographic information ethics as a form of holistic knowledge.

Third, we should acknowledge the fact that geographic information ethics, in practice, are graded not monolithic. As noted previously, despite the ubiquitous mapping circumstances, there is still an unbridgeable gap in status between the administrator of a digital archive and the users who post. As previous PGIS projects inevitably generated an anisotropic (interactive but not bidirectional) social relationship between those who empower and/or manage and those who are empowered and/or participate in terms of jurisdictional authority (Rambaldi et al., 2006; Fox et al., 2008), we should consider how to provide new insights into cultivating an ethical consciousness according to one's own power and status.

In cyberspace, the power of rumours may encompass reputational damage to a complete stranger about repulsive properties, who is sometimes unaware of it. Therefore, ethics and norms for administrators would be more practical and technically feasible. In contrast, ordinary users are more likely to confuse themselves with their online psyche, and sometimes even utilise GIT to casually offend someone for pleasure. The author has 
termed these roles Cyber-COP and geovigilante, respectively (Suzuki, 2018; Suzuki, forthcoming). Apparently, they are not fully aware of the outcomes, as in the case where the individual tweeted a death threat. The important thing in ubiquitous mapping circumstances is that even children can compete with the professional mass media in terms of information gathering and broadcasting abilities. Therefore, further studies should develop geographic information ethics to address this newly emerging phenomenon, and we should be aware of the social role that geography education can play. Even though such education cannot deter single-minded fanaticism, it may prevent juveniles from inappropriate behaviour stemming from a sudden impulse or simple ignorance.

Fourth, we should fully use scientific knowledge in the contiguous areas of specialisation. Above all, comparative jurisprudence and information ethics are important. For example, in deepening our consideration of the ethical problems involved, it is vital to understand what privacy is and how it has been discussed. In fact, privacy has been discussed in the field of information ethics since the 1970s. The classic conceptualisation of privacy, which regards privacy infringement as trespassing on private space (Warren and Brandeis, 1890) is now understood as a multi-layered concept that includes the right of choice over privacy options (Westin, 1967) and making accountable the party who infringes on those rights (Moor, 1997). Every legislative system and ethical standard in different regions or states places different emphases on these three components.

On 25 May 2018, the Vienna-based non-profit organisation, noyb.eu, filed four complaints of 'forced consent' against Google, Instagram, WhatsApp, and Facebook based on the enforcement of the General Data Protection Regulation (GDPR) because the privacy protections in the GDPR outweigh those in the US (Safari, 2016; noyb.eu., 2018). This reflects the differences in legal norms regarding privacy components. Thus, to achieve a better understanding of geographic information ethics 2.0, it is essential that it be based on knowledge of comparative jurisprudence and information ethics.

\section{Acknowledgements}

This work was supported by JSPS KAKENHI Grant Number JP17H00839. Some parts of this article were based on the following conference presentations conducted by the author: the 63rd Annual Conference of The Japanese Society for Ethics in 2012, the Kyoto Collegium for Bioethics in 2014, the conferences of the Association of Japanese Geographers in 2014 and 2015, GISTAM 2018, and a keynote speech at Hokuriku GeoSpatial Forum 2017.

\section{References}

Armstrong, M.P. (2002). Geographic Information Technologies and Their Potentially Erosive Effects on Personal Privacy. Studies in the Social Sciences 27(1), 19-28.

Carraro, V. and Wissink, B. (2018). Participation and Marginality on the Geoweb: The Politics of Nonmapping on OpenStreetMap Jerusalem. Geoforum 90, 64-73.

Chapin, M., Lamb, Z., and Threlkeld, B. (2005). Mapping Indigenous Lands. Annual Review Anthropology 34, 619-638.

Crampton, J.W. (2010). Mapping: A Critical Introduction to Cartography and GIS, Wiley-Blackwell, Malden, MA.

Dagnall, N., Denovan, A., Drinkwater, K., Parker, A. and Clough, P.J. (2017). Urban Legends and Paranormal Beliefs: The Role of Reality Testing and Schizotypy. Frontiers in Psychology 8, 1-13.

Dobson, J. E. and Fisher, P. F. (2007). The Panopticon's Changing Geography. Geographical Review 97(3), 307323.

Fox, J. (2002). Siam Mapped and Mapping in Cambodia: Boundaries, Sovereignty, and Indigenous Conceptions of Space. Society and Natural Resources 15(1), 65-78.

Fox, J., Suryanata, K., Hershock, P., and Pramono, A.H. (2006). Mapping Power: Ironic Effects of Spatial Information Technology. Participatory Learning and Action 54(1), 98-105.

Fox, J., Suryanata, K., Hershock, P., and Pramono, A.H. (2008). Mapping Boundaries Shifting Power: The Socio-ethical Dimensions of Participatory Mapping. In: Goodman, M.K., Boykoff, M., Evered, K.T. eds. Contentious Geographies: Environmental Knowledge, Meaning, Scale. pp.203-217. Ashgate, Hampshire, UK.

Furuta, Y. (2010). Marude fudōsan-ban Wikileaks! 'Ōshima teru' no shōtai wa? (Wikileaks of real estate! (so to speak). Who is Oshimateru?) http://ascii.jp/elem/000/000/578/578237/. (in Japanese) last accessed 2018/09/20

Gartner, G., Bennett, D. A., and Morita, T. (2007). Towards Ubiquitous Cartography. Cartography and Geographic Information Science 34(4), 247-257.

Girres, J. F. and Touya, G. (2010). Quality Assessment of the French OpenStreetMap Dataset. Transactions in GIS 14(4), 435-459.

Goodchild, M.F. (2007). Citizens as Sensors. GeoJournal 69(4), 211-221.

Haklay, M., Singleton, A., and Parker, C. (2008). Web Mapping 2.0: The Neogeography of the GeoWeb. Geography Compass 2(6), 2011-2039.

Harris, T. and Weiner, D. (1998). Empowerment, Marginalization and "Community-integrated" GIS. Cartography and GIS 25(2), 67-76.

Kaneko, H. (2015). Chintai-nin ga, Tatemono-nai de Jisatsu ga atta Jijitsu wo Koi ni Chinshaku-nin ni 
Tsugenakatta koto ga Fuhō Kōi wo Kōsei suru to Sareta Jirei (A Precedent Whereby the Lessor Did not Deliberately Notify the Lessee of the Fact that the Suicide History of the Property Constituted a Tort). RETIO 98, 136-137. (in Japanese)

Kawaguchi, Y. and Kawaguchi, K. (2012). What Does Google Street View Bring about? -Privacy, Discomfort and the Problem of Paradoxical Others-. Contemporary and Applied Philosophy 4, 19-34.

Kingsbury, P. and Jones, J.P. (2009). Walter Benjamin's Dionysian Adventures on Google Earth. Geoforum 40, 502-513

Koskela, H. (2002). 'Cam Era'-The Contemporary Urban Panopticon. Surveillance \& Society 1(3), 292313.

McCall, M.K. and Dunn, C.E. (2012). Geo-information Tools for Participatory Spatial Planning: Fulfilling the Criteria for 'Good' Governance?. Geoforum 43, 81-94.

Miller, H. (2007). Place-based versus People-based GIScience. Geography Compass 1(3), 503-535.

Ministry of Justice. (2018). Japanese Law Translation. http://www.japaneselawtranslation.go.jp/. last accessed 2018/09/20

Moor, J.H. (1997). Towards a Theory of Privacy in the Information Age. Computer \& Society 27(3), 27-32.

Morita, T. (2005). A Working Conceptual Framework for Ubiquitous Mapping. Proceedings of XXII International Cartographic Conference. A Courna, Spain.

Nagashima, K. (2018). Issues in Civil Enforcement Law of Psychological Defects. The Review of Takushoku University: Politics, Economics and Law 20(2), 143-162. (in Japanese)

Nakato, Y. (2015). Kyojū Mokuteki no Tochi Baibai ni kanshi Kinrin Jūmin no Kioku ni Nokoru 20-nen Ijō Mae no Jisatsu Jiken-tō ni tsuki Baikai Gyōsha no Setsumei Gimu ga Mitome Rareta Jirei (A Precedent that Gained Legal Acceptance Whereby the Duty of a Real Estate Broker to Disclose the 20-year-old Suicide History of a House to the Lessee, Who Wanted to Reside in the House, Became a Memorable Event among the Neighbouring Residents). RETIO 98, 126127. (in Japanese)

Neteler, M., Bowman, M.H., Landa, M. and Metz, M. (2012). GRASS GIS: A Multi-purpose Open Source GIS. Environmental Modelling \& Software 31, 124-130. noyb.eu. (2018). GDPR: Noyb.eu Filed Four Complaints over "Forced Consent" against Google, Instagram, WhatsApp and Facebook, https://noyb.eu/wpcontent/uploads/2018/05/pa_forcedconsent_en.pdf. last accessed 2018.08.06.

Norheim-Hagtun, I. and Meier, P. (2010). Crowdsourcing for Crisis Mapping in Haiti. Innovations 5(4), 81-89.

Oshima, M. (2014). Jiko-bukken wa Ichinichi ni Shite Narazu!? Shōtai Fumei (Saikin Sōdemo Nakunatte Kita) no Jiko-bukken Shōkai Saito 'Oshima Teru' Kanrinin wo Chokugeki! (Oshimaland wasn't Built in a Day!?:
Direct Interview to the Enigmatic Web-administrator of the Stigmatized Properties). Rooftop, Arg.2014. https://rooftop.cc/interview/140801180000.php. (in Japanese) last accessed 2018.09.21

Perkins, C. and Dodge, M. (2009). Satellite Imagery and the Spectacle of Secret Spaces. Geoforum 40, 546-560.

Rambaldi, G., Chambers, R., McCall, M., and Fox, J. (2006). Practical ethics for PGIS practitioners, facilitators, technology intermediaries and researchers. Participatory Learning and Action 54(1), 106-113.

Reichenbacher, T. (2007). Adaptation in Mobile and Ubiquitous Cartography. In: William C., Peterson, M.P., and Gartner, G. (eds.) Multimedia Cartography, pp. 383-397. Springer. Berlin Heidelberg.

Rinner C. (1999). Argumaps for Spatial Planning. Proceedings of the First International Workshop on TeleGeoProcessing, Lyon, May 6-7, 95-102.

Rose-Redwood, R.S. (2006). Governmentality, Geography, and the Geo-coded World. Progress in Human Geography 30(4), 469-486.

Safari, B.A. (2016). Intangible Privacy Rights: How Europe's GDPR will Set a New Global Standard for Personal Data Protection. Seton Hall Law Review 47, 809-848.

Seto, T. (2011). Spatiotemporal Transition of Volunteered Geographic Information as a Response to Crisis: A Case Study of the Crisis Mapping Project at the Time of Great East Japan Earthquake. Papers and Proceedings of the Geographic Information Systems Association 20, B-2-4. (in Japanese)

Shilton, K. (2009). Four Billion Little Brothers?: Privacy, Mobile Phones, and Ubiquitous Data Collection. Communications of the ACM 52(11), 48-53.

Sieber, R. (2006). Public Participation Geographic Information Systems: A Literature Review and Framework. Annals of the Association of American Geographers 96(3), 491-507.

Sui, D.Z. (2008). The Wikification of GIS and Its Consequences: Or Angelina Jolie's New Tattoo and the Future of GIS. Computers, Environment and Urban Systems 1(32), 1-5.

Suler, J. (2004). The Online Disinhibition Effect. CyberPsychology \& Behavior 7(3), 321-326.

Suzuki, K. (2018). A Newly Emerging Ethical Problem in PGIS - Ubiquitous atoque Absconditus and Casual Offenders for Pleasure. Proceedings of the 4th International Conference on Geographical Information Systems Theory, Applications and Management, 22-27.

Suzuki, K. (forthcoming). Emergence of Geovigilantes and Geographic Information Ethics in the Web 2.0 Era. In: Barbosa, S.D.J., Filipe, J., Kotenko, I., Sivalingam, K.M., Washio, T., Yuan, J., Zhou, L. eds. Communications in Computer and Information Science. Berlin, Springer.

Talen, E. (2000). Bottom-up GIS. Journal of the American Planning Association 66, 279-294. 
Turner, A.J. (2006). Introduction to Neogeography. O'Reilly Media, Inc.

Verplanke, J., McCall, M.K., Uberhuaga, C., Rambaldi, G. and Haklay, M. (2016). A Shared Perspective for PGIS and VGI. The Cartographic Journal 53(4), 308317.

Viégas, F. B., Wattenberg, M. and Dave, K. (2004). Studying Cooperation and Conflict between Authors with History Flow Visualizations. Proceedings of the SIGCHI Conference on Human Factors in Computing Systems 6(1), 575-582.

Warren, S.D., Brandeis, L.D. (1890). The Right to Privacy. Harvard Law Review 4(5), 193-220.

Weiner, D., Warner, T., Harris, T.M., and Levin, R.M. (1995). Apartheid Representations in a Digital Landscape: GIS, Remote Sensing, and Local Knowledge in Kiepersol, South Africa. Cartography and Geographic Information Systems 22, 30-44.

Westin, A. (1967). Privacy and Freedom. Athenum, New York.

Whitaker, R. (1999). The End of Privacy: How Total Surveillance is Becoming a Reality. The New Press, New York.

Williams, C. and Dunn, C.E. (2003). GIS in Participatory Research: Assessing the Impact of Landmines on Communities in North-west Cambodia. Transactions in GIS 7, 393-410.

Willis, N. (2011). OpenStreetMap Project Imports US Government Maps, https://www.linux.com/news/openstreetmap-projectimports-us-government-maps. last accessed 2018/06/24. 